\title{
Peculiarities of biographical research for the analysis of the informal teacher education
}

\author{
Irena Zemaitaityte ${ }^{1, *}$, Giedre Pauriene ${ }^{2}$, and Alina Petrauskiene ${ }^{3}$ \\ ${ }^{1}$ Educational Science and Social Work Institute, Mykolas Romeris University, Vilnius, Lithuania \\ ${ }^{2}$ Public Security Academy, Department of Humanities, Mykolas Romeris University, Vilnius, \\ Lithuania \\ ${ }^{3}$ Educational Science and Social Work Institute, Mykolas Romeris University, Vilnius, Lithuania
}

\begin{abstract}
The article reviews peculiarities of biographical research. Emphasis is placed on the experiences determined by the biographical circumstances, which have served educators as impetus for informal studies, as well as founding layers for the growth of pedagogical professional competencies. When discussing lifelong learning and the growing demands on educators' professionalism, it is most important to understand how the competences of the teaching profession develop in informal learning; next, it is possible to identify the structures that enable this process. The aim of the article is to reveal the peculiarities of a biographical method and the expression of pedagogical competences of the pedagogical professionals formed through informal learning and stimulated by biographical circumstances. The analysis and results of the obtained data base on the study logic of the construction of the abduction theory according to Peirce and the Grounded theory methodology according to Strauss and Corbin [1]. The research revealed that the processes of informal learning, critical for the competencies of an educator's profession, take their route in childhood. Learning experiences in childhood, as well as further biographical experiences not only determine the interest in the pedagogical profession, but also determine pedagogical abilities and values.
\end{abstract}

Key words: biographical research, pedagogical professional competencies, informal learning.

\section{Introduction}

The society today is placing increasing demands on educators in terms of professionalism, teaching efficiency, personal qualities and other aspects. In order to meet these requirements, educators have to participate not only in traditional forms of in-service training, but also search for various alternative forms of learning that enable continuous, individual and flexible learning [2]. According to researchers [2-6], compared to formal learning, much less attention is paid to non-formal and informal learning in such social institutions as the family, various organizations, clubs, community, etc. These areas still lack the attention of education policy makers and researchers. Therefore, it is necessary to give more importance to informal learning, giving individuals more opportunities to develop existing and acquire new competencies [3]. The skills that educators bring to their professional activities, acquired during informal learning and education, receive no acknowledgement. No attention

\footnotetext{
* Corresponding author: irene@mruni.eu
}

(C) The Authors, published by EDP Sciences. This is an Open Access article distributed under the terms of the Creative Commons Attribution License 4.0 (http://creativecommons.org/licenses/by/4.0/). 
is directed towards the procedures and contexts of the development of such professional competencies. Therefore it is important to understand the peculiarities of the formation of these competencies in informal learning, to analyze the factors of their development. In this way, the professional development of educators becomes a lifelong process, and biographical method allows receiving an in-depth knowledge of the peculiarities of this multifaceted phenomenon.

This article presents a study, whose research problem is articulated in the question: how do biographical circumstances determine the manifestations of the competences of the pedagogical profession through informal learning?

The aim of the article is to reveal the peculiarities of the biographical method and the expression of pedagogical competences of the pedagogical professionals formed through informal learning and stimulated by biographical circumstances.

To achieve this goal, the following tasks have been set:

1. To substantiate the suitability of the biographical research in order to reconstruct the development of pedagogical professional competencies through informal learning.

2. To analyze the expression of pedagogical professional competencies determined by biographical circumstances.

Research methods: theoretical methods - analysis of scientific pedagogical and psychological literature, generalization, and empirical one - qualitative research method. Biographical narrative interview is applied, and data analysis bases on Strauss and Corbin [1] The Grounded Theory (GT) and "formative interpretation" according to Bohnsack [7].

\section{Biographical research and the interpretative paradigm of informal learning}

Recent decades have seen an increase in biographical approach in research in the social sciences. This is related to the formation of new identities determined by the changes of the postmodern world order and social and economic environments, focus on individuality and the diversity of unique meanings in subjectively experienced reality. Biographical method and the specific life story told by a person become essential tools for the analysis of the expression of individual experience in a changing social and cultural environment [8-10].

According to Kasatkina [11], the totality of biographical narratives becomes the object of analysis, designed to accumulate the collective experience of surviving a certain social situation. Comparative analysis of similar cases becomes the basis for recognition of a social problem through awareness of common social practice of people, their interaction and context. This methodology allows creating a typology of life strategies in similar situations, to construct "samples" of behaviour, normative models of lifestyles and cultural values.

Tracing back since 1990s, biographical method has become a strong theory-generating tradition of research not only in the science of education but also in other social sciences such as sociology and history. All these disciplines, using biographical method, seek to obtain information about cultures, social strata of society and daily life, seek to reveal from the subject's position how the research participants construct their social reality and what conditions are perceived as determining the manifestation of a certain phenomenon. Learning and educational processes become possible when learners insert new knowledge and cognitive potential into the existing biographical horizon, expanding it as if going beyond the boundaries of existing experience and knowledge structures [12]. According to Krüger and Marotzki [13], the biographical method in education can be applied to the analysis of individual learning and educational processes. 
Both the concept of informal learning and the biographical method base on a broad concept of learning that links learning to the biography bearer's life experiences and highlights the learning embedded in these experiences [14]. The role of 'biographically' has a special role to play here [12], i.e. people are able to attach certain meanings to skills, experiences, information, and incidents and through this act include all into the frame of biography. When people are asked to tell about their lives, they begin to construct their biographies into which they consistently incorporate their lives.

Attributing biographical research to an interpretive paradigm provides an opportunity to understand the reality constructed by the characters, i. how they accept society's demands on them, how they reproduce or vary social rules and structures, and how at the same time they develop individual perseverance's toward a goal [15]. As Alheit and Dausien [16] observes, lists of learning experiences can be interpreted as stories, which help to manage lives, and which convey the knowledge and skills that have helped a person to cope with life's problems. The human life experience is the foundation of learning processes, and especially in adult learning, and research work.

Various definitions of the concept of biographical access are used in the methodological literature and in the tradition of qualitative research. The variety of terms often complicates the very concept of biographical research. This approach is often equated with the concept of "life story", "life narrative", "narrative" or "biographical narrative" [17]. The concept of life history is usually based on an individual's autobiographical narrative, covering his or her entire life cycle or most of his or her life. The narrative is conveyed in the form and style chosen by the person, and can be recorded orally or in writing [18]. Researchers using a "narrative" or "personal narrative" approach focus on the nature of the narrative and the form of the story being told. Narrative in this case is understood as "a narrative consisting of separate, successive events with the beginning, the middle, and the end" [10]. From a narrative perspective, life is experienced by perceiving and accepting the past, present, and future [17]. In capturing the thematic narrative of experiences, this study seeks to identify the significance of societal myths and narratives for individual narratives [10].

\subsection{Research methodology}

The analysis and results of the obtained data are based on the logic of the study of the construction of the abduction theory according to Peirce [19] and the methodology of the Grounded theory (GT) according to Strauss and Corbin [1]. The term "abduction" (Latin abducere meaning to take away, lead away) is associated with the work of a researcher, philosopher and logic Charles Sanders Peirce [19], who not only provided a clear logical form for this type of analysis, but was also the first to use the term. The abduction research strategy is characterized as "generating social scientific reports, opinions, assessments based on reports, opinions, assessments found in everyday social reality" [20]. By means of the abduction strategy, we attempted to describe and understand the expression of the educators "competences stimulated by their biographical circumstances in terms of the research participants" motives and opinions / assessments. Fragments of the meanings of social life presented by the research participants are later "pasted" into the entire description of the phenomenon.

The research database consists of 8 biographical narrative interviews that were collected and analyzed in the period 2014-2016. The research population is pedagogues with at least 7 years of pedagogical work experience, regardless of the educational institution in which they work. This criterion for selecting informants - pedagogical experience - was chosen on the basis of Hubermann's [21] model of development of an educator's professional competence. It linked an educator's professional competence not to an educator's age but 
to their pedagogical experience, stating that after about 7 years of pedagogical work in the profession a perception of stability and confidence establishes, as well as the desire to experiment and to re-evaluate oneself forms. Some of the informants were selected according to the "snowball principle". The Grounded theory seeks to collect as much and as varied data as possible from the field of study [22]. Therefore, each study participant was selected basing on the criterion of supplement, i.e. how much new information a participant can potentially add to the data already available.

Biographical-narrative interviews started with the same introductory question: "I am interested in how you would explain the formation of your professional skills. How and where did you acquire the knowledge, abilities, and skills required in your profession? What determined your choice to become a teacher in your life? How does today's life affect your profession and abilities? - Maybe let us start just in a simple way, tell your life story in as much detail as possible. I will not interrupt during your narration, but I will ask my questions after your narration." The introductory question was followed by immanent questions, i.e. questions that relate to what has already been said and what more would like to be further clarified. With the consent of informants, we recorded the interviews and later transcribed them. The duration of the interviews varied from 0:59 p.m. to 2:48 p.m. (average interview duration $-1: 12$ hours).

Prior to the data coding process, a "formative interpretation" was performed according to Bohnsack [7] to account for the requirements of the sequence of events principle. The biographical narrative was presented from a third-person perspective, emphasizing the totality of the sequence of biographical events, thus highlighting the thematic structure of the research data. This methodology was intended to overcome the problem of compatibility of the sequence of biographical events and GT, because, according to Rosenthal [15], GT does not meet the requirements of the sequence of events principle, which is especially important in biographical research. It is Rosenthal [15], who suggests a "formative interpretation" as a solution to the above problem.

\subsection{Research results}

The pedagogue's personality and the nature of his/her professional activity have a special place, in the educational process. Pedagogical activities take place in a "person-to-person" relationship and especially require social skills that allow for easy communication with other people. The ability to communicate and interpret is an essential element of the competences of the pedagogical profession (general, didactic, subject), the development of which, as the results of the research show, can be determined by biographical circumstances. For example, an educator who, as a child, helped prepare lessons for their younger brother and counselled classmates during breaks, asked what the significance of this experience was for her competence, says:

"I remember my brother stumbling over something in math. He was three years younger than me and I sat down to help him. The father was then making jokes, Well, oh, I'm trying to explain, and you're sitting down and everything is in place." (Interview A, 47-49)

"After listening to my ... lesson... teaching during the breaks, let's say... well, they were already ready to get by ... in the lesson itself. Yes... my... well, I don't know ... maybe a pedagogical (3) determination was formed." (Interview A, 55-57)

In other words, innate principles were educated - gifts whose development results in abilities [23]. Many modern talent theories emphasize that talents are not static, talents manifest differently in different activities. The talents of some gifted people become apparent in 
childhood and can be noticed by those around them. If those people held their trust, then their insights are likely to have an effect on an individual's self-perception:

"When we were sent from the fourth grade to the fifth grade, though in the very same school, but the words of my first teacher were and they still ring in my ears: "You will be a teacher and nothing else." [Excitement] (...)The seventh grade teacher sending us to the eighth grade of high school (3) with wishes for everyone, of course ... and again, as if prophesying [excitement] to me.... Well, you, of course, will be ... a teacher." (Interview A, 31-32, 43-45)

The childhood inclinations, self-awareness become the basis for further development of one's abilities and acquisition of new ones. The self-consciousness of "being an explainer" that emerged in childhood later becomes a central part of professional identity:

"I felt that I really enjoyed communicating with my classmates and explaining things they didn't understand. (...) I really liked, as I said, being an explainer. (...) I was surrounded during breaks: "tell me, tell me how, what, what". Mostly from the social sciences, where there is no need to count or grammar rules to write, where to tell, it is history, geography maps. I stood surrounded, telling and showing." (Interview A, 27-28.46-47,182-185)

A retrospective look at the learning experience in childhood gives an individual the opportunity to develop his or her individual knowledge that is relevant and meaningful to him or her today. Adaptation to a new generation of learners leads to an informal learning process.

"It might be I'm thinking the way I was, I'm looking at these kids. I understand why they're like that, because they need something new, and in that sense, the times are changing." (Interview D, 307-308)

Pedagogical abilities, like many other human qualities, are partly innate, partly developed. We inherit some of them, others are formed in childhood, and still others are formed throughout life. However, innate abilities can be further developed and improved. Individuals themselves do not always have a clear understanding of the development of pedagogical skills through biographical processes. In this case, we can talk about latent learning as an integral part of informal learning. Latent learning occurs when a learner learns unconsciously, i.e. unconsciously taking over certain actions by observing and paying attention to something. One informant, talking about her organizational ability to plan her and others' time, does not admit that she could have developed this ability, while another notices that observing her mother's professional activity brought her closer to her current profession:

"I don't know how parents can teach. I don't think so... How can they teach you to plan and allocate time? I don't think so. I think it is either... Like I said, I can't argue, maybe you can get it, in my case, it wasn't. I didn't get it, I think I have it innate ... and just in practice... yet... I saw how it goes into practice what is needed ... and just I was able to apply those innate things." (Interview B, 350-355)

"I was no stranger, my mother worked as a teacher and I saw the whole kitchen as things go." (Interview C, 14-15)

The competencies of the pedagogical profession base on common human values, which are followed by all pedagogues in their professional activities. Above all, it is respect for the person and responsibility for their performance. We identify the conditions for the development of a sense of responsibility in biographical circumstances related to close family members:

"It must be stemming from the family here, such an inoculated trait to do the job well. If you do something... you have to do well. (..) My mommy was like that, always said 
that... well, any job is honourable, but you have to try, you have to do, you have to do well. (..) That's ... that probably helps me a lot now too, that any job at work, ... is what I'm doing now that I have to do well... And it's up to me how I do the job." (Interview B, 395-401)

"Well, it would be a shame not to study well, because my mother was a teacher, well, and somehow that was already in the blood, well, what else must be done, well, I was learning." (Interview C, 277-278)

Responsibility, as a character trait, according to Leman [24], can be influenced by an individual's place among siblings, which can also lead to his or her further development. The following biographical circumstances are revealed in the informant's narrative, when the first childhood memories are associated with the little brother:

"Ever since I started to remember... my... life... maybe when my brother was born. (...) I remember the City Garden, I remember my brother in a wheelchair... The same first impressions of childhood, infancy." (Interview A, 6-9)

It should be noted that for the firstborn, the development of responsibility begins early, which is related to the responsibilities that have arisen. In this case, one can assume that first memories of childhood testify to a strong expression of the informant's sense of responsibility, and the following quote illustrates this:

"I have to admit, I was quite diligent, I prepared my lessons diligently and I still seemed to have some responsibility towards my classmates. I will probably need to consult them today as well." (Interview A, 52-55)

That sense of responsibility, an understanding of the need to improve through informal learning, is felt throughout the biographical narrative. Biographical circumstances that have forced us to walk new professional paths are also emphasized, and informally acquired competencies seem to become the basis for determination to change in professional life:

"And life turned that way that...... I needed of them [former teachers, existing coworkers, auth. note] to learn. (...) Something had to be done, and since because I was an engineer, but with higher education and working in pedagogical work only with children of that age." (Interview A, 41-42, 140-141)

In addition to the socialization processes that have taken place in the family and led to the acquisition of certain competencies, there are also examples of close people mentioned, they set a standard to follow their lives and become landmarks in their professional paths. Undoubtedly, the processes of informal learning are related to such situations, which, respectively, promote the development of competencies of the pedagogical profession, as well as the formation of values - in this case, respect for the person. A certain approach to the child is taken from one respondent's former teacher, who was "absolutely different and fascinated", and this approach is applied in current pedagogical activities:

"I had great teachers, and from whom later... I could learn later. (...) Then I turn to my very best educators for the thoughts that taught me. I remember their lessons, I use their methodology, and, I can't complain, I succeed." (Interview A, 40-41, 115-116),

Biographical experiences augment not only the approach to the teaching profession, but also the competence of the teaching profession, such as the ability to solve problems:

“... my dear parents were ill too, I had to take care of them, and I had to bury them, and... the children were small, well, it was just a very difficult year and now that you think about when you start comparing, ... if it's a problem,... let's say at work, perhaps, another would say, it is already a very big problem, to be or not to be.. So, let's say, at 
my pedagogical work I think so, that any problem can be solved and that this is not the end of the world, because, in fact, there are many bigger problems, there are much harder things in life than that, say, to solve one or other problem, at my pedagogical work. This personally me helps to look at certain problems in my life, now in pedagogical work and to solve them." (Interview B, 386-393)

Long-term pedagogical work as a biographical experience influences the change of an individual's personal characteristics and attitudes, which is significant for the competencies of the pedagogical profession.

"With the years, maybe I'm calmer... I look with more tolerance at everything around me.
I realize I won't change everything I want. Maybe this taught me to adapt a little more, to
adjust... As is around... (...) But that attitude came, in the sense that I understand that
he doesn't do bad things, he does it differently. When I was younger, it seemed to me that
if the way of acting differs from mine, then it was wrong. There were two opinions, mine
and the wrong. Maybe that is what has changed in life" (G interview, 355-357, 364-366)

We can look at this change as an outcome of informal learning. The tolerant attitude mentioned is primarily related to respect, acceptance and correct understanding of the means of self-expression and the expression of human individuality.

\section{Main findings}

The study of biographies, seeing the informants' narratives as an expression of individual identity, makes it possible to grasp the unique path of one's life from the past, encompassing the present and the implied future. By remembering and retelling one's experience at different stages of life, a person can become better aware of it, identify feelings, experiences and their meaning. The influence of the social environment is significant for an individual's constructed life history, as biographical narratives are not expressing individual and unique models of the self. In constructing an individual narrative, individuals take over social categories that already exist in the social environment. Learning and educational processes take place on the horizon of individual biographical experiences and expectations. Individuals along the way of their lives constantly supplement the potential of their knowledge, skills and attitudes and this supplement is reflected in their individual biographies. Then, using the qualitative method of biographical research, we can trace the dimension of informal learning and reveal possible processes of competence development.

Informal learning processes that are important for the competencies of the teaching profession begin in childhood. Both the choice of the teaching profession and the personal competencies predisposing to the teaching profession are stimulated by biographical circumstances. Learning experiences in childhood, further biographical experiences not only determine the interest in the pedagogical profession, but also develop pedagogical skills, allow augmenting one's knowledge. Both the level of general competence development, didactic and subject competences, are highlighted in this survey. Not always, the individual perceives informal learning processes consciously.

The pedagogical potential observed and named by people close to the respondents, as well as the inclinations formed in childhood toward certain activities, self-awareness become the basis for further development of one's abilities and skills and influence the processes of informal learning. The development of personal characteristics and values is most difficult to fathom and evaluate, but in this survey, such development is identified in biographical circumstances related to close family members and persons who have become professional authorities for the learner. 


\section{References}

[1] A.L. Strauss, J. Corbin, Grounded Theory. Grundlagen qualitativer Sozialforschung (Weinheim, 1996)

[2] M. Heise, Informelles Lernen von Lehrkräften. Ein Angebots-Nutzungs-Ansatz. Empirische Erziehungswissenschaft, Band 16. - Münster: Waxmann Verlag (2009)

[3] W. Hamacher et al., Sicherheits - und Gesundheitskompetenz durch informelles Lernen im Prozess der Arbeit. Forschung Projekt F 2141. Dortmund/Berlin/Dresden (2012)

[4] I. Žemaitaitytè, Non-formal adult education in Lithuania. in Society. Integration. Education: proceedings of the scientific conference, May 26th-27th, Rezekne: Rezekne Academy of Technologies 2, 577-585 (2017)

[5] G. Paurienè, Savaiminio (informaliojo) mokymosi sampratos analizė // Visuomenès saugumas ir viešoji tvarka (10): mokslinių straipsnių. Kaunas: MRU P.181-197 (2013)

[6] M. Teresevičienè, G. Gedvilienè, V. Zuzevičiūtè, Andragogika (Kaunas, Vytauto Didžiojo universiteto leidykla, 2006)

[7] R. Bohnsack, Rekonstruktive Sozialforschung (9., überarbeitete und erweiterte Auflage) (Opladen, Budrich 2014)

[8] R. Indriliūnaite, Gyvenimo istorijos tyrimo perspektyvos: benamystès atvejis. Kultūra ir visuomenè. Socialiniụ tyrimų žurnalas 7(2), (2016)

[9] B. Roberts, Biographical Research (Buckingham: Open University Press, 2002)

[10] B. Merrill, L. West, Using Biographical Methods in Social Research (Thousand Oaks, CA: Sage Publications, 2009)

[11] N. Kasatkina, Biografinio metodo taikymo patirtis, FILOSOFIJA. SOCIOLOGIJA 2, 33-39 (2005)

[12] P. Alheit, Geschichten und Strukturen. Methodologische Überlegungen zur Narrativität. Zeitschrift für Qualitative Forschung 8, 75-96 (2007)

[13] H. H. Krüger, W. Marotzki, Handbuch erziehungswissenschaftliche Biographieforschung (Leske + Budrich Verlag, 2006)

[14] H. Von Felden, Bildung und Biographie. Zur Erschließung von Bildungsprozessen in Lebensgeschichten durch Differenzierung des narrationsstrukturellen Verfahrens. In: Koller, Hans-Christoph, Wulftange, Gereon (Hrsg.): Lebensgeschichte als Bildungsprozess? Perspektiven bildungstheoretischer Biographieforschung. Bielefeld: transcript, 103-125, (2014).

[15] G. Rosenthal, Interpretative Sozialforschung: eine Einführung. Weinheim (Basel: Beltz Juventa, 2015)

[16] P. Alheit, B. Dausien, Biographieorientierung und Didaktik. Überlegungen zur Begleitung biographischen Lernens in der Erwachsenenbildung. In: Report. Literaturund Forschungsreport Weiterbildung 28(3), 27-36 (2005)

[17] A. Barabasch, B. Merrill, Res. Comparative Int. Edu. 9(3), 287-300 (2014)

[18] S.E. Chase, Narrative Inquiry: Multiple Lenses, Approaches and Voices, in The Sage Handbook of Qualitative Research (3rd edition) (Thousand Oaks, CA: Sage Publications, 2005), pp. 651-679

[19] C.S. Peirce, Peirce on Signs: Writings on Semiotic (University of North Carolina Press, Chapel Hill, NC, 1991)

[20] N. Blaikie, Designing Social Research. The Logic of Anticipation (Cambridge: Polity, 2000) 
[21] M. Huberman, Der berufliche Lebenszyklus von Lehrern. Ergebnisse einer empirischen Untersuchung. edited by E. Terhart (Hrsg.): Unterrichten als Beruf. Neuere amerikanische und englische Arbeiten zur Berufskultur und Berufsbiographie von Lehrerinnen und Lehrern. Köln. 249-267 (1991)

[22] A. Straus, Grundlagen der Qualitativen Sozialforshcung (München, 1998)

[23] L. Jovaiša, Pedagogikos terminai (Kaunas, Šviesa, 1993)

[24] K. Leman, The Birth Order Book: Why You Are the Way You Are (USA, Revell, 2015) 